\title{
ANALISA DAYA DUKUNG DAN PENURUNAN PONDASI TIANG BOR (BORED PILE)TUNGGAL DENGAN MENGGUNAKAN PROGRAM PLAXIS ( Studi Kasus: Proyek Pembangunan Yogya Toserba II Majalengka )
}

\author{
Adi Guna Prakasa ${ }^{1}$, Arief Rijaluddin ${ }^{2}$ \\ Teknik Sipil, Fakultas Teknik Universitas Majalengka \\ email: aguzmilan22@yahoo.co.id ${ }^{2}$
}

\begin{abstract}
Bored Pile Foundation is a foundation type applied to transfer payload from structural part to upper/upper structure to soil layer below under it's untill bearing capacity wanted, hence required a part of contrsruction building under/sub-structure without existence of risk from shear disrepair or over setlement.

Purpose of research is analysis level of foundation bearing capacity of single bored pile and setlement happened from some methods conventionally, what based on assaying data in field and with finite element method applies program Plaxis where modelling of soil is Mohr Coulomb. Then does analysis and comparison from result of calculation with the methods is upper.
\end{abstract}

Keyword : Plaxis, Mohr Coulomb

\section{PENDAHULUAN}

Perkembangan sebuah wilayah/kota dapat terlihat dari segi pembangunan infrastruktur yang terus dilakukan dan pertambahan penduduk yang semakin meningkat. Mengakibatkan kebutuhan dan penggunaan lahan terus bertambah, sehingga pembangunan tersebut berdampak pada lahan tersedia yang menjadi semakin sempit.

Proyek Pembangunan Yogya Toserba II Majalengka yang berlokasi di Jln. KH. Abdul Halim No. 110 merupakan gagasan yang telah direncanakan oleh pihak Owner(pemilik) PT. Akur Pratama. Mengingat Yogya Toserba yang sudah ada pada ruas jalan yang sama tidak dapat menampung jumlah pengunjung pada hari libur terutama pada area parkir yang tersedia. Atas dasar tersebut pihak Owner (pemilik)PT. Akur Pratama membangun lagi Yogya Toserba II dengan area parkir dan area pertokoan yang

lebih luas dengan luas area lahan yang berkisar antara $7000-7250 \mathrm{~m}^{2}$, pada bangunan pertokoan memiliki ketinggian \pm 16 meter yang terdiri dari 3 lantai.

Berdasarkan data hasil penyelidikan tanah di lokasi proyek Yogya Toserba II Majalengka diperoleh bahwa tanah lapisan atas adalah tanah lempung kelanauan atau tanah berbutir halus, sedangkan lapisan tanah keras di titik sondir S01 berada pada kedalaman $3,00 \mathrm{~m}$, titik S-02 berada pada kedalaman $3,20 \mathrm{~m}$, titik $\mathrm{S}-03$ berada pada kedalaman 3,40 m, di titik S-04 berada pada kedalaman 4,20 m dengan kedalaman MAT (Muka Air Tanah) adalah 1,00-1,50 m. Untuk jenis pondasi yang digunakan pada bangunan pertokoan Yogya Toserba Majalengka yaitu pondasi tiang bor tunggal (bored pile) dengan kedalaman dan diameter yang berbeda.

Pondasi Tiang Bor (bored pile) memiliki berbagai permasalahan, terutama pada saat pelaksanaan penggalian lubang tiang yang dapat mengakibatkan perubahan perilaku tanah dan permasalahan yang ada sangat kompleks, kondisi tanah kohesif dilokasi proyek dan jenis pondasi yang digunakan tentu saja harus diperhatikan beberapa hal diantaranya : a). Bagaimana besar penurunan (settlement) pada tanah yang akan berpengaruh terhadap konstruksi tersebut, dan besarnya pergeseran tanah terutama pada pondasi dalam (deep foundation) yang akan mempengaruhi daya 
dukung pondasi tersebut. b). Bagaimana menghitung besarnya daya dukung pondasi sehingga penggunaan jenis pondasi dapat ditentukan berdasarkan hasil dari penyelidikan tanah yang telah dilakukan.

Tujuan dan Manfaat Penelitian ini sebagai berikut :

a. Menganalisa besarnya penurunan (settlement) tanah yang terjadi pada pondasi bored pile tunggal tersebut menggunakan program PLAXIS dengan pemodelan tanah Mohr Coulumb

b. Menganalisa daya dukung pondasi bored pile tunggal dengan perbandingan beberapa metode perhitungan daya dukung pondasi, diantaranya :
a). Metode Meyerhof,
b). Metode Aoki \& de Alencar,
c). Metode de Ruiter \& Beringen, dan
d). Metode Reese \& Wrigth,

Manfaat dari penelitian ini adalah :

a. Mengetahui besarnya penurunan pondasi tiang bor dengan metode perhitungan menggunakan program PLAXIS

b. Mengetahui beberapa perbandingan perhitungan daya dukung pondasi dengan metode perhitungan berdasarkan teori yang berbeda - beda.

Lokasi penelitan pada studi kasus yaitu Proyek Yogya Toserba II Majalengka Jalan KH. Abdul Halim No. 110 Kecamatan Majalengka, Kabupaten Majalengka.

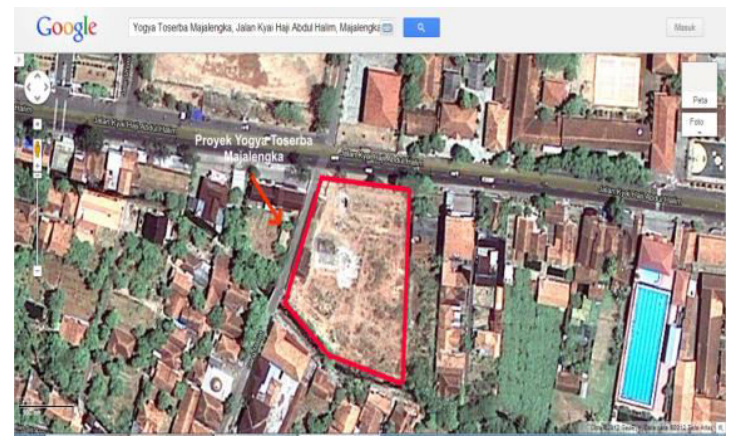

Gambar 1. Lakasi Penelitian

\section{METODE PENELITIAN}

\subsection{Tahapan Penelitian}

Berdasarkan data hasil penyelidikan tanah di lokasi proyek Yogya Toserba II Majalengka diperoleh bahwa tanah lapisan atas adalah tanah lempung kelanauan atau tanah berbutir halus, sedangkan lapisan tanah keras di titik sondir S01 berada pada kedalaman 3,00 m, titik S-02 berada pada kedalaman $3,20 \mathrm{~m}$, titik S-03 berada pada kedalaman $3,40 \mathrm{~m}$, di titik S-04 berada pada kedalaman 4,20 $\mathrm{m}$ dengan kedalaman MAT (Muka Air Tanah) adalah $1,00-1,50 \mathrm{~m}$

Ada beberapa tahapan dalam menganalisa daya dukung pondasi tiang bor (bored pile) juga penentuan penurunan/ setlementyang terjadi, berdasarkan rumusrumus dari beberapa metode secara konvensional yang didasarkan pada data-data pengujian dilapangan ataupun data hasil pengujian di laboratorium. Menentukan penurunan/ setlement dengan menggunakan program Plaxis dimana pemodelan tanah adalah model Mohr Coulumb, kemudian membuat suatu kesimpulan dari hasil analisis dan perhitungan maupun saran yang diberikan dari hasil tersebut.

Metodologi yang digunakan dalam penelitian dapat dilihat pada diagram Flow Chart pada Gambar 2.1.

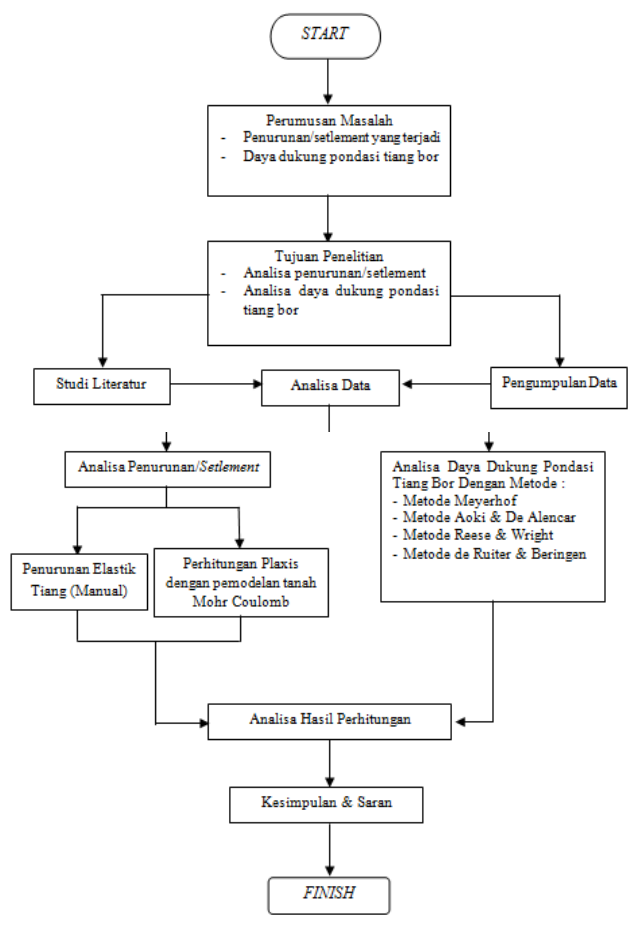

Gambar 2.1 Tahapan Penelitian

\section{Deskripsi Alur Penelitian}

Dalam penelitian ini tahap pertama dalam proses analisa adalah dengan menentukan permasalahan yang terjadi dalam proyek tersebut, kasus yang ada dan perlu dikaji lebih lanjut sehingga dapat menimbulkan manfaat untuk perkembangan ilmu ketekniksipilan. Seperti yang telah dipaparkan dalam diagram Flow Chart pada Gambar 3.1, adapun tujuan yang akan dicapai dalam penelitian ini diantaranya : 
Jurnal J-Ensitec: Vol 03|No. 01, November 2016

a. Menganalisa besarnya penurunan (settlement) tanah yang terjadi pada pondasi bored pile tunggal tersebut menggunakan program PLAXIS dengan pemodelan tanah Mohr Coulumb

b. Menganalisa daya dukung pondasi bored pile tunggal dengan perbandingan beberapa metode perhitungan daya dukung pondasi

\subsection{Analisa Penrunan/Setlement}

Data-data yang telah didapat berupa data sekunder dan data primer akan dipakai dalam proses analisa perhitungan/ calculation, dimana analisa tersebut berdasarkan pada studi literatur dan kajian teori-teori yang mendukung proses penelitian. Proses analisa data yang dilakukan memiliki beberapa tahapan, mengingat analisa penurunan/ setlementyang terjadi adalah menggunakan software Plaxis dan perhitungan daya dukung pondasi tiang bor.

Proses analisa penurunan/ setlement yang terjadi dapat dilihat dalam diagram Flow Chart pada gambar 2.2 dibawah ini.

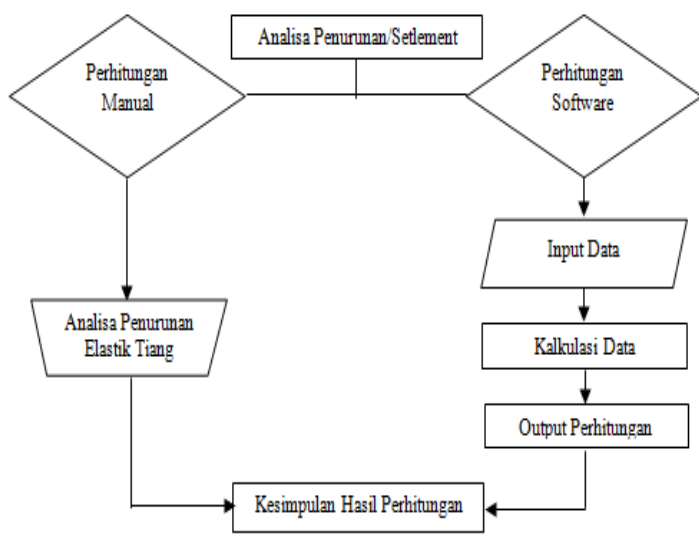

Gambar 2.2 Diagram Flow Chart Analisa Penurunan/Setlement

\section{HASIL DAN PEMBAHASAN}

\subsection{Data Teknis Pondasi Tiang Bor/Bored Pile}

Data-data yang berkaitan dengan pelaksanaan teknis dilapangan didapatkan dari pihak kontraktor PT. Gatra Kencana, Bandung. Adapun data teknis pondasi tiang bor/bored pile sebagai berikut :
1) Kedalaman : Tergantung

Pondasi Tiang Bor Pada Lapisan

Tanah Keras

(Diperoleh dari data sondir)

2) Diameter Bored : $\quad \varnothing 800 \mathrm{~mm}$ Pile

$\varnothing 1000 \mathrm{~mm}$

Ø $1200 \mathrm{~mm}$

3) Mutu Beton

4) Mutu

K $225 ; \mathrm{f}^{\prime} \mathrm{c}=$ $18.675 \mathrm{MPa}$

: BJTP - 30

Baja/Tulangan

(Polos)

BJTD -24

(Ulir)

5) Diameter Tulangan : D13 (Ø $13 \mathrm{~mm})$

6) Jumlah Pile Cap : Dapat dilihat \&Bored Pile

pada lampiran

7) Denah Pondasi : Dapat dilihat Bored Pile pada lampiran

8) Denah Pondasi : Dapat dilihat Bored Pile (Penunjuk Analisa Daya Dukung)

9) Detail Pondasi Bored Pile

: Dapat dilihat pada lampiran

\subsection{Proses Analisa Perhitungan Pada Program Plaxis 2D (Student Version)}

Ada beberapa tahapan dalam analisa programfinite element method adapun langkahlangkah secara lebih detail ada pada Panduan Modul Penggunaan Program Plaxis 2D v.8.5 (Student Version).

\section{A. Proses Penggambaran Geometri \& Stratifikasi Tanah \\ Didalam penggambaran stratifikasi tanah} pada program plais 2D Student Version, terdapat 3 jenis lapisan tanah, adapun tipe pile yang dianalisa didalam perhitungan pada program plaxis 2D Student Version adalah Tipe Pile P2A yang berada di grid B-5. Untuk dimensi pile yang digambarkan didalam penggambaran geometri pada program Plaxis Student Version adalah $1 / 2 \mathrm{D}(\mathrm{D}=$ diameter pile).

Untuk penggambaran geometri pada program Plaxis Student Version dapat dilakukan dengan memasukan titik koordinat dari setiap titik, ataupun dapat langsung digambarkan dengan mengklik kursor yang ada. gambar untuk geometri dan stratifikasi tanah dapat dilihat pada gambar 5.1 dibawah 
Jurnal J-Ensitec: Vol 03|No. 01, November 2016

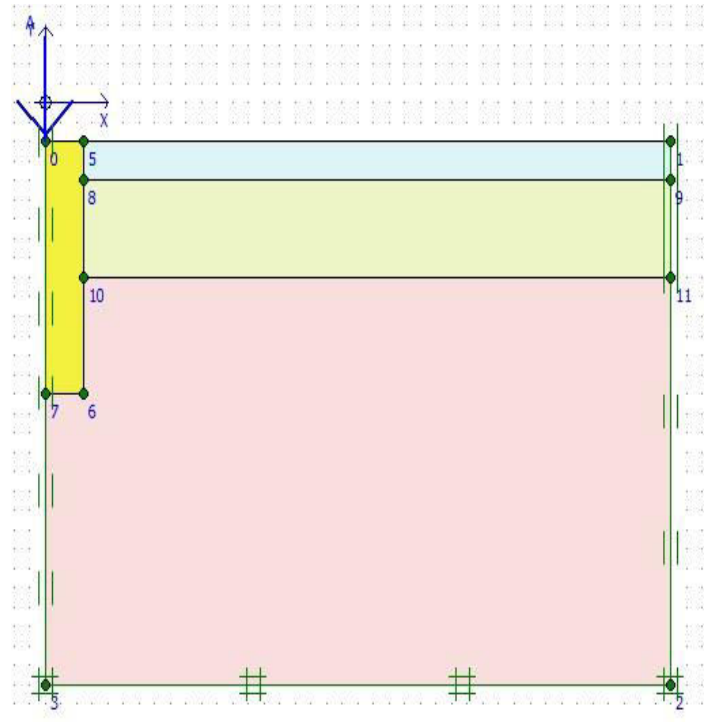

Gambar 3.1 Geometri \& Stratifikasi Tanah

Tabel 3.1 Titik Koordinat Pada Penggambaran Geometri \& Stratifikasi

\begin{tabular}{|c|c|c|}
\hline \multirow{2}{*}{ No. Titik } & Point X & Point Y \\
\cline { 2 - 3 } & $(\mathrm{m})$ & $(\mathrm{m})$ \\
\hline \hline 1 & 0.00 & -0.40 \\
\hline 2 & 8.00 & -0.40 \\
\hline 3 & 8.00 & -6.00 \\
\hline 4 & 0.00 & -0.40 \\
\hline 5 & 0.50 & -3.00 \\
\hline 6 & 0.50 & -3.00 \\
\hline 7 & 0.50 & -0.80 \\
\hline 8 & 8.00 & -0.80 \\
\hline 9 & 0.50 & -1.80 \\
\hline 10 & 8.00 & -1.80 \\
\hline
\end{tabular}

\section{B. Proses Input Data}

Pada proses analisa perhitungan menggunakan program plaxis di perlukan datadata input untuk soil properties dan pile properties, adapun data-data tersebut yaitu :

Tabel 3.2 Data Input Soil Properties Pada Lap.1

\begin{tabular}{|c|l|c|}
\hline No. & \multicolumn{1}{|c|}{$\begin{array}{c}\text { Data Input Untuk Soil } \\
\text { Properties (Lap.1) }\end{array}$} & Nilai \\
\hline \hline 1 & $\gamma_{\text {sat }}$ (Berat Jenis Tanah Sat.) & $19.4 \mathrm{kN} / \mathrm{m}^{3}$ \\
\hline 2 & $\begin{array}{l}\gamma_{\text {unsat }} \text { (Berat Jenis Tanah } \\
\text { Unsat.) }\end{array}$ & $10.39 \mathrm{kN} / \mathrm{m}^{3}$ \\
\hline 3 & $\mathrm{k}_{\mathrm{x}}$ (Permeabilitas) & $\begin{array}{c}4.5 \times 10^{-4} \\
\mathrm{~m} / \mathrm{day}\end{array}$ \\
\hline 4 & $\mathrm{k}_{\mathrm{y}}$ (Permeabilitas) & $\begin{array}{c}4.5 \times 10^{-4} \\
\mathrm{~m} / \mathrm{day}\end{array}$ \\
\hline 5 & $\mathrm{E}_{\text {ref }}$ (Modulus Elastisitas) & $\begin{array}{c}2415000.339 \\
\mathrm{kN} / \mathrm{m}^{2}\end{array}$ \\
\hline 6 & $v_{\text {nu }}$ (Poisson Ratio) & 0.49 \\
\hline 7 & $\mathrm{C}_{\mathrm{ref}}$ (Kohesi Tanah) & $38.30 \mathrm{kN} / \mathrm{m}^{2}$ \\
\hline 8 & $\varphi$ (Sudut Geser dalam) & $30^{\circ}$ \\
\hline 9 & $\psi$ (Sudut Dilatansi) & $\begin{array}{c}{ }^{\circ}(\text { Clay } \\
\text { Soil) }\end{array}$ \\
\hline
\end{tabular}

Tabel 3.3 Data Input Soil Properties Pada Lap.2

\begin{tabular}{|c|l|c|}
\hline No. & \multicolumn{1}{|c|}{$\begin{array}{c}\text { Data Input Untuk Soil } \\
\text { Properties (Lap.2) }\end{array}$} & Nilai \\
\hline \hline 1 & $\gamma_{\text {sat }}$ (Berat Jenis Tanah Sat.) & $20.9 \mathrm{kN} / \mathrm{m}^{3}$ \\
\hline 2 & $\begin{array}{l}\gamma_{\text {unsat }} \text { (Berat Jenis Tanah } \\
\text { Unsat.) }\end{array}$ & $14.90 \mathrm{kN} / \mathrm{m}^{3}$ \\
\hline 3 & $\mathrm{k}_{\mathrm{x}}$ (Permeabilitas) & $\begin{array}{c}4.5 \times 10^{-4} \\
\mathrm{~m} / \mathrm{day}\end{array}$ \\
\hline 4 & $\mathrm{k}_{\mathrm{y}}$ (Permeabilitas) & $\begin{array}{c}4.5 \times 10^{-4} \\
\mathrm{~m} / \mathrm{day}\end{array}$ \\
\hline 5 & $\mathrm{E}_{\text {ref }}$ (Modulus Elastisitas) & $\begin{array}{c}2415000.339 \\
\mathrm{kN} / \mathrm{m}^{2}\end{array}$ \\
\hline 6 & $v_{\mathrm{nu}}$ (Poisson Ratio) & 0.49 \\
\hline 7 & $\mathrm{C}_{\mathrm{ref}}$ (Kohesi Tanah) & $125.99 \mathrm{kN} / \mathrm{m}^{2}$ \\
\hline 8 & $\varphi($ Sudut Geser dalam) & $32^{\circ}$ \\
\hline 9 & $\psi($ Sudut Dilatansi) & $0^{\circ}($ Clay Soil) \\
\hline
\end{tabular}

Tabel 3.4 Data Input Soil Properties Pada Lap.3

\begin{tabular}{|c|l|c|}
\hline No. & \multicolumn{1}{|c|}{$\begin{array}{c}\text { Data Input Untuk Soil } \\
\text { Properties (Lap.3) }\end{array}$} & Nilai \\
\hline \hline 1 & $\gamma_{\text {sat }}$ (Berat Jenis Tanah Sat.) & $21.7 \mathrm{kN} / \mathrm{m}^{3}$ \\
\hline 2 & $\begin{array}{l}\gamma_{\text {unsat }} \text { (Berat Jenis Tanah } \\
\text { Unsat.) }\end{array}$ & $18.83 \mathrm{kN} / \mathrm{m}^{3}$ \\
\hline 3 & $\mathrm{k}_{\mathrm{x}}$ (Permeabilitas) & $\begin{array}{c}4.5 \times 10^{-4} \\
\mathrm{~m} / \mathrm{day}\end{array}$ \\
\hline 4 & $\mathrm{k}_{\mathrm{y}}$ (Permeabilitas) & $\begin{array}{c}4.5 \times 10^{-4} \\
\mathrm{~m} / \mathrm{day}\end{array}$ \\
\hline 5 & $\mathrm{E}_{\text {ref }}$ (Modulus Elastisitas) & $\begin{array}{c}2415000.339 \\
\mathrm{kN} / \mathrm{m}^{2}\end{array}$ \\
\hline 6 & $v_{\mathrm{nu}}$ (Poisson Ratio) & 0.49 \\
\hline 7 & $\mathrm{C}_{\mathrm{ref}}$ (Kohesi Tanah) & $213.07 \mathrm{kN} / \mathrm{m}^{2}$ \\
\hline 8 & $\varphi$ (Sudut Geser dalam) & $34^{\circ}$ \\
\hline 9 & $\psi$ (Sudut Dilatansi) & $0^{\circ}($ Clay Soil) \\
\hline
\end{tabular}

Tabel 3.5 Data Input Pile Properties/Material Properties

\begin{tabular}{|c|c|c|}
\hline No. & $\begin{array}{c}\text { Data Input Untuk Pile } \\
\text { Properties }\end{array}$ & Nilai \\
\hline 1 & $\begin{array}{c}\gamma_{\text {unsat }} \text { (Berat Jenis Beton } \\
\text { Betulang) }\end{array}$ & $24 \mathrm{kN} / \mathrm{m}^{3}$ \\
\hline 2 & $\begin{array}{l}\mathrm{E}_{\text {ref }} \text { (Modulus Elastisitas } \\
\text { Beton) }\end{array}$ & $\begin{array}{c}629866975.9 \\
\mathrm{kN} / \mathrm{m}^{2}\end{array}$ \\
\hline 3 & $v_{\mathrm{nu}}($ Poisson Ratio $)$ & 0.15 \\
\hline
\end{tabular}

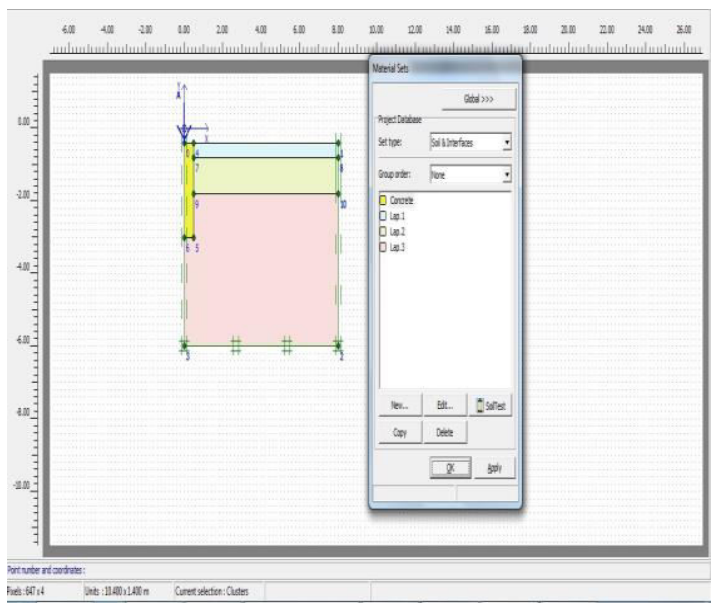

Gambar 3.2 Tampilan Input Soil Properties \& Pile Properties/Material Properties 
Setelah penggambaran geometri \& stratifikasi tanah, penginputan data Lap.1 sampai Lap. 3 juga data pile properties (tiang bor) selesai dilakukan, maka langsung dilakukan pengaktifan struktur tanah kedalam perhitungan metode elemen hingga dengan perintah Generate Mesh. Maka struktur tanah akan menyatu dan membentuk 3 elemen node.

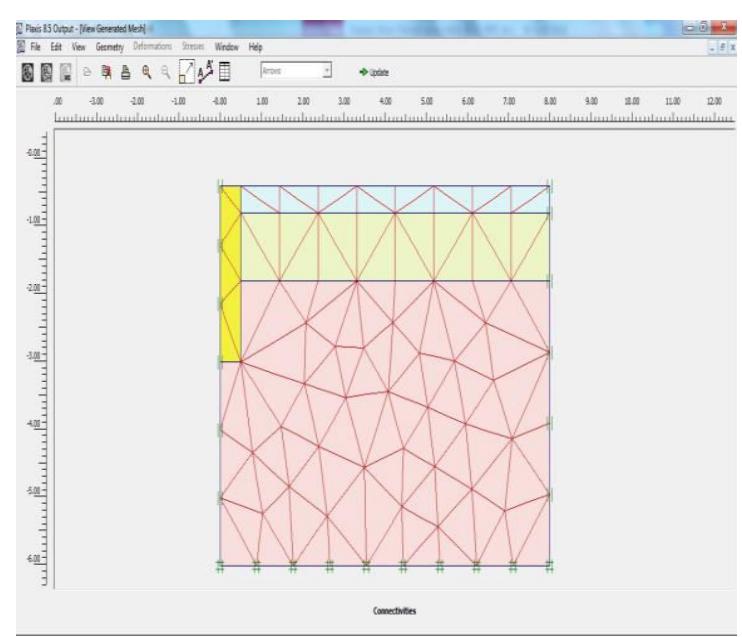

Gambar 3.3 View Generated Mesh

Kemudian dilanjutkan dengan memasukan Ground Water Level pada Preatic Level. Kedalaman M.A.T pada Proyek Yogya Toserba II Majalengka terletak pada kedalaman $-1.00 \mathrm{~m}$ sampai $-1.50 \mathrm{~m}$.

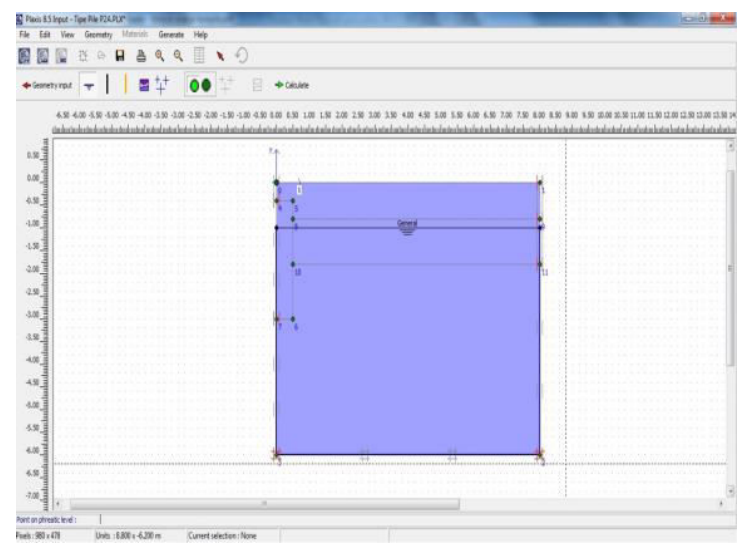

Gambar 3.4 Ground Water Level Initial Condition

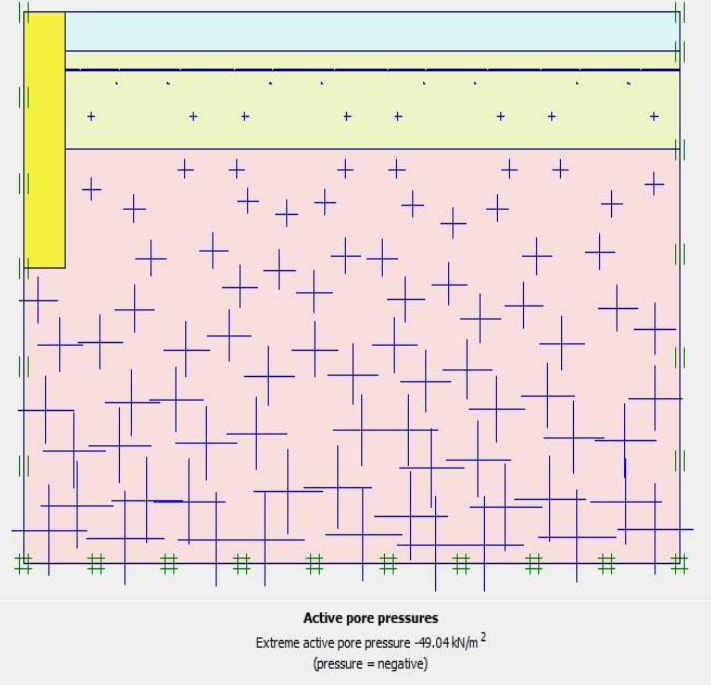

Gambar 3.5 Active Pore Pressure

Langkah selanjutnya adalah dengan Generate Initial Stress, untuk memberikan pengaruh tegangan terhadap badan tanah (Soil Body) dari berat material tanah tersebut.

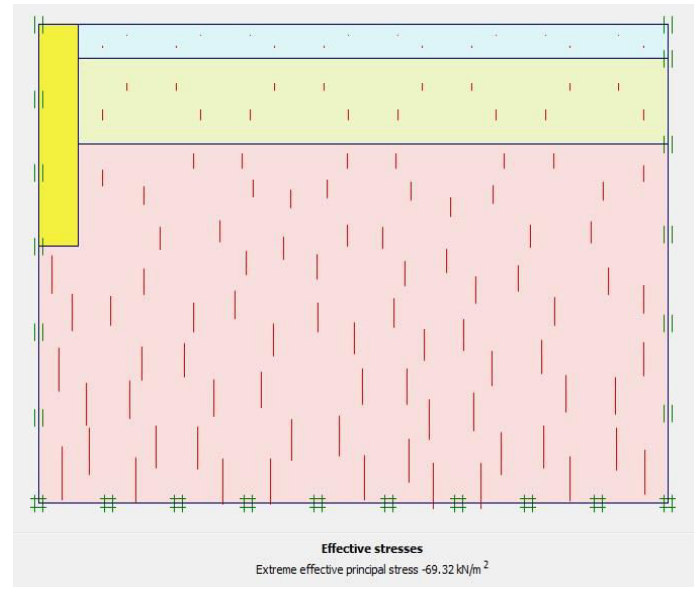

Gambar 3.6 Initial Effective Stresses

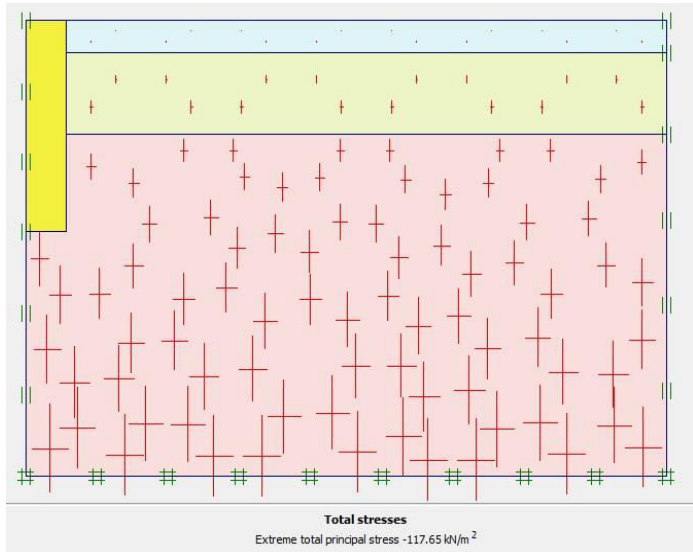

Gambar 3.7 Initial Total Stresses 


\subsection{Proses Kalkulasi Data}

Terdapat 3 phase kalkulasi pada tipe pile P2A yang dilakukan didalam program plaxis 2D Student Version, diantaranya :

1) Phase 1 ( Tahap Kontruksi ), meliputi :

- Calculation Type: Plastic Calculation

- Loading Input : Staged Construction

(Klik Define Untuk Mengaktifkan Pondasi)

2) Phase 2 ( Tahap Pembebanan / Load 1x ), meliputi :

- Calculation Type : Plastic Calculation

- Loading Input : Staged Construction

(Klik Define Untuk Aktifkan Beban

Point Load A $=-32.740 \mathrm{kN} / \mathrm{m}^{3}$ )

Data beban diperoleh dari kajian analisa perhitungan struktur baja Agus Mulyadi pada proyek Yogya Toserba II Majalengka. (data beban dilampirkan)

3) Phase 3 ( Tahap Pembebanan / Load 5x ), meliputi :

- Calculation Type : Plastic Calculation

- Loading Input : Total Multipliers

- Input Values : Total Multipliers $\Sigma$ Mload A = 5

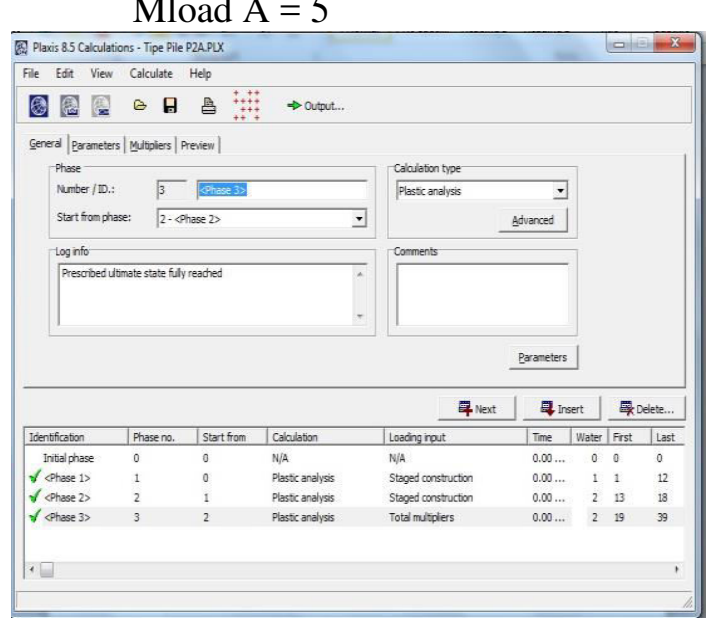

Gambar 3.8 Tampilan Proses Kalkulasi

\section{Output Hasil Perhitungan Plaxis 2D (Student Version)}

Setelah proses kalkulasi data selesai, maka langkah selanjutnya adalah dengan memunculkan output hasil analisa. Ada beberapa hasil output perhitungan diantaranya :

- Deformed Mesh, menampilkan gambaran deformasi penurunan struktur tanah dan bentuk elemen tanah tersebut.

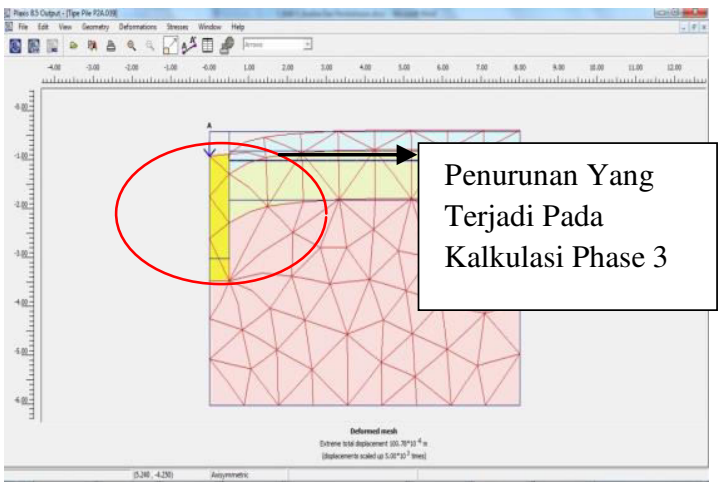

Gambar 3.8 Deformed Mesh Yang Terjadi Pada Kalkulasi Phase 3

Berdasarkan hasil analisa plaxis 2D Student Version pada proses kalkulasi, penurunan tanah yang terjadi bila di masukan beban Point Load A $=-32.740 \mathrm{kN} / \mathrm{m}^{3}$ (Load $5 \mathrm{x}$ $=-163.7 \mathrm{kN} / \mathrm{m}^{3}$ ) adalah :

$$
\begin{aligned}
& \text { Extreme Total }=100.78 \times 10^{-6} \mathrm{~m} \\
& \text { Displacement (Scaled Up } 5 \times 10^{3} \text { ) } \\
& =0.00010078 \mathrm{~m} \\
& =0.10078 \mathrm{~mm}
\end{aligned}
$$

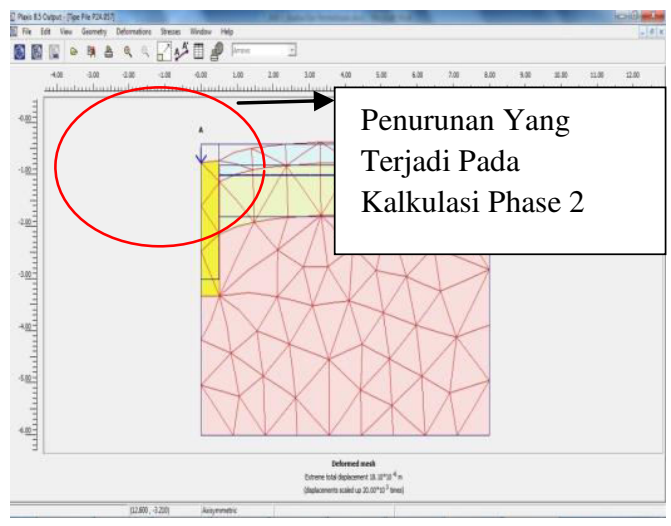

Gambar 5.9 Deformed Mesh Yang Terjadi Pada Kalkulasi Phase 2

Berdasarkan hasil analisa plaxis 2D Student Version pada proses kalkulasi, penurunan tanah yang terjadi bila di masukan beban Point Load $\mathrm{A}=-32.740 \mathrm{kN} / \mathrm{m}^{3}$ adalah :

$$
\begin{aligned}
\text { Extreme Total }= & 18.10 \times 10^{-6} \mathrm{~m} \\
\text { Displacement } & (\text { Scaled Up } 5 \mathrm{x} \\
& \left.10^{3}\right) \\
= & 0.0000181 \mathrm{~m} \\
= & \mathbf{0 . 0 1 8 1} \mathrm{mm}
\end{aligned}
$$


Untuk hasil secara keseluruhan output dari proses kalkulasi dapat dilihat secara jelas didalam lampiran.

\section{KESIMPULAN}

\subsection{Kesimpulan Hasil Penelitian}

Dari hasil perhitungan yang telah dilakukan dengan beberapa perhitungan metode berdasarkan data-data penyelidikan lapangan ataupun data korelasi yang di peroleh dari berbagai sumber, maka dapat diketahui beberapa macam hal diantaranya kesimpulan berdasarkan hasil perhitungan analisa daya dukung ataupun kesimpulan berdasarkan hasil perhitungan setlement/ penurunan pondasi tiang bor.

A. Kesimpulan Hasil Analisa Daya Dukung

- Dari ke 4 metode analisa daya dukung nilai $\mathrm{Q}_{\mathrm{u}}, \mathrm{Q}_{\mathrm{s}}$, dan $\mathrm{Q}_{\mathrm{p}}$ Metode Reese \& Wrigth yang memiliki nilai terbesar $\mathrm{Q}_{\mathrm{u}}(\max )=2939.98$ ton, $\mathrm{Q}_{\mathrm{s}}(\max )=$ 88.78 ton, $Q_{p}(\max )=2851.20$ ton. Sedangkan untuk $\mathrm{Q}_{i}$ dengan nilai terbesar ada di metode Meyerhof $\mathrm{Q}_{\mathrm{i}}$ $(\max )=773.02$ ton. Hasil dari keseluruhan perhitungan daya dukung pondasi tiang bor dapat dilihat di lampiran.

- Semakin besar diameter pondasi maka semakin besar daya dukung ujung yang disalurkan.

- Jenis daya dukung pondasi tiang berdasarkan hasil perhitungan adalah termasuk End Bearing Pile, karena daya dukung ujung tiang lebih besar dibandingkan dengan daya dukung selimut tiang.

\section{B. Kesimpulan Hasil Perhitungan Setlement/Penurunan Pondasi Tiang Bor}

- Berdasarkan dari hasil perhitungan manual yaitu besar penurunan elastik tiang terbesar adalah berada di Tipe Pile P2A, P2 (Grid B-5 \& C-5) dan Tipe Pile P2A (Grid I-5) sebesar 6.6674 mm - $6.6854 \mathrm{~mm}$

- Untuk hasil perhitungan pada program plaxis 2D Student Version, untuk Tipe Pile P2A (Grid B-5) memiliki penurunan tanah sebesar $\mathbf{0 . 1 0 0 7 8} \mathbf{~ m m}$ (Cal. Phase 3) dan $\mathbf{0 . 0 1 8 1 ~} \mathbf{~ m m ~ ( C a l . ~}$ Phase 2)
- Batas penurunan elastik tiang terbesar pada Proyek Yogya Toserba II Majalengka masih normal, jauh dari batas maksimal penurunan untuk bangunan umum $25.4 \mathrm{~mm}$ atau 2.54 $\mathrm{cm}$.

\section{REFESENSI}

Bowless J.E. 1996. Foundation Analysis and Design $5^{r d}$ edition. New York : Mc-Graw Hill.

Hardiyatmo, H. C. 2002. Teknik Pondasi 2. Yogyakarta : Beta Offset

Hardiyatmo.H.C. 2001. Teknik Pondasi Jilid 1 \& 2. Jakarta :Gramedia

Ir. Sosrodarsono, Suyono. \& Kazuto, Nakazawa. 2000. Mekanika Tanah \& Teknik Pondasi. Jakarta:PT Pradniya Paramita

M Braja.Das. 2010.Principles of Foundation Engineering 6th (Sixth Edition). USA:Cangage Learning.

M Braja.Das. 2011.Principles of Foundation Engineering 7th (Seventh Edition). USA:Cangage Learning.

Prof. Ir. Shidarta, S.K. Rekayasa Fundasi II Fundasi Dangkal dan Fundasi Dalam. Jakarta:Guna Darma

Santosa, Budi. Suprapto, Heri \& HS, Suryadi. Dasar Mekanika Tanah (Seri Diktat Kuliah). Guna Darma

Santosa, Budi. Suprapto, Heri \& HS, Suryadi. Mekanika Tanah Lanjutan (Seri Diktat Kuliah). Guna Darma

Santosa, Budi. Suprapto, Heri \& HS, Suryadi. Mekanika Tanah Lanjutan (Seri Diktat Kuliah). Guna Darma

Titi, Abu-Farsakh. 1999. "Evaluation of Pile Load Tests in Soft Cohesive Louisiana Soils". American: ASCE Geotechnical Special Publication GSP 88. 